\title{
A computational line of comprehension of account
}

\author{
Marioara Avram ${ }^{1}$, Aurelia Traistaru ${ }^{2, *}$ \\ ${ }^{1}$ University of Craiova, 13 A. I. Cuza Street, Craiova, 200585, Romania \\ ${ }^{2}$ Matei Basarab High School, Craiova, Romania \\ *E-mail address: traistaru_aurelia@yahoo.com
}

\begin{abstract}
The study creates a trail of computational explaining of the account and balance sheet as nuclear structure of the elements functioning of an entity. The main working tool used for situation and patrimony elements movement recording is the account. The balance sheet presents the situation of the patrimony elements at a time, leading to a broader scope, while the account has a much narrower scope, referring only to a patrimonial element - genre or test case - included in the balance sheet but about which shows both the situation at a time and the modifications which are registered over periods of time. By its form, the account allows the separate registration of the increases and movements in a given period and establishing of the existence of the patrimonial element anytime. By account is also performed a systematization of economic and financial operations.
\end{abstract}

Keywords: financial operations; account; balance; registration

JEL: M40, M41

\section{INTRODUCTION}

With the accounts, accounting records, monitors and controls existing and changes associated with each economic good, source of finance and phases of each economic process (Băndoi \& Tomiţă, 2009; Borowski, 2014). Through the balance sheet cannot be represented economic and financial operations that took place in the year ended. Therefore, the balance presents the situation of the patrimonial elements of the entity at a particular time, the account refers to one of the patrimonial elements of balance sheet and presents its situation at a time, and changes appeared during the reporting period.

Functions of accounts:

1. economic function consist of that each account reflects a certain economic good, source of funding, business process or financial result;

2. statistic function lies in that the data and information supplied by of accounts can be reflected through certain statistical indicators;

3. computing function allows the calculation of patrimonial elements in different moments of economic activity;

4. control function consists of using data and information supplied for property control integrity exercising of entity patrimony, spending level control, etc.; 
5. grouping function on homogeneous elements (economic goods, financing resources and economic processes);

6. systematization function consists in separate recording of economic operations and financial that generates changes to increase or rise, of those that determines decreases or depreciate of the same element.

Bilateral form of the account: in one of the parties is recorded initially existing and increases, and decrease in the other. For example, in case of accounts associated with funding sources, the records are as follows: initial existences and increases are recorded in the right side and decreases in left side (Berceanu, 2008; Siminică, 2008).

\section{THE STRUCTURE OF THE ACCOUNT}

The structure of the account consists of name and symbol of the account, date and explanation of the account, parts of the account: debit and credit, cash flow and total amount, balance account.

The name or title of account represents the name through which is identified the patrimonial element (economic good, source of financing, economic process or financial result). The symbol of the account is the digital symbol composed of three or four digits. This symbol is found in General Plan of Accounts. It is attached to each account to make easier the accounting job;

\section{Ex. The account "merchandise", symbol 371 \\ The account "bank in LEI", symbol 5121}

Date refers to the moment of roll on or registration, if applicable, the respective economic-financial operation being defined: day, month, year.

Explication of economical operation can be:

- descriptive it presents briefly the content of the operation by indicating the justificatory document and of its the number in which the operation has been recorded;

- accountable indicating the name or symbol of the correspondent account.

Debit and credit represent the two parts of account that define the balance form. The account is a specific procedure of accounting method through which is assured valued registration, chronologic, systematic of existence and movement of patrimonial elements.

The debit and credit scheme is as follows:

\begin{tabular}{|c|c|}
\hline $\begin{array}{c}\text { The left side of an account is called } \\
\text { DEBIT }\end{array}$ & $\begin{array}{c}\text { The right side of an account is called } \\
\text { CREDIT }\end{array}$ \\
\hline $\begin{array}{c}\text { Registered amount in the debit of an } \\
\text { account are called DEBIT }\end{array}$ & $\begin{array}{c}\text { Registered amount in the debit of an } \\
\text { account are called CREDIT }\end{array}$ \\
\hline $\begin{array}{c}\text { To debit an account means to register } \\
\text { economical-financial operation in } \\
\text { DEBIT account }\end{array}$ & $\begin{array}{c}\text { To credit an account means to register } \\
\text { economical-financial operation in }\end{array}$ \\
CREDIT account
\end{tabular}

The debit and credit of account must not be confused with the ACTIVE and PASIVE of balance sheet. 
Cash Flow shows valued changes of patrimonial elements, of their increase or decrease, determined by economic operations in a period of time (Smarandache \& Vlăduţescu, 2014).

Total amount is obtained by adding of all the amounts recorded in the debit account under the name total debit amounts receivable, and by adding all the amounts recorded in the credit account, the total credit amount payable.

Account Balance represents the existing value at a certain time of the patrimonial element for which was opened the account. It is determined as the difference between the total debits and total credits. Therefore we can identify the following results: if the total debits is greater than the total credits the account shows a debit balance, when the total credits is greater than the total debits, the account shows a credit balance. When the total debits is equal to the total credits, its balance is zero, balanced account.

Initial Balance $=$ existence at the beginning of period, which is taken over of previous balance Sheet.

$\begin{aligned} \text { Current Balance }= & \begin{array}{l}\text { Initial balance } \\ \text { of Patrimonial } \\ \text { elements }\end{array}+\begin{array}{l}\text { Increase of } \\ \text { Patrimonial } \\ \text { elements }\end{array}\end{aligned}-\begin{aligned} & \text { Decrease of } \\ & \text { Patrimonial } \\ & \text { Elements }\end{aligned}$

Account closing is made before of drawing up the balance sheet by passing the final balance in the side where the total amount is less. Account opening is made by taking over at the beginning of next period of existing (balances) by registering them in the side from where them originated.

\section{THE RULES OF ACCOUNTS OPERATING}

There are 3 rules of accounts operating:

R1. Assets Accounts start operating by debit and are debited with the existences of assets, and liability accounts start operating through credit and are credited with the existences of liabilities.

R2. Assets Accounts also are debited with the increases, rising, memorizing, inputs etc.. of the assets elements and liability accounts also are credited with the increases, rising, memorizing, inputs etc.. of the liabilities elements.

R3. Active accounts are credited with decreasing, minimizations, depreciations, outputs etc. of the assets elements and liability accounts are debited with the decreasing, minimizations, depreciations, outputs etc. of liabilities elements.

Assets accounts always have final debtor balance or are balanced, and liability accounts always have the final credit balance or are balanced. Assets accounts start to operate through debiting, and the liability accounts through crediting. Single purpose accounts are those at the end of the reporting period always presents one kind of balance, debit or credit. They are always only asset or liability account (Dima \& Vlăduţescu, 2012; Vlăduţescu \& Ciupercă, 2013). Bifunctional accounts are those that may be at a time either debit balance or credit balance, so in some cases operating after the rules of the assets accounts, and in others, of the liability accounts. 


\section{DOUBLE ENTRY BOOKKEEPING AND ACCOUNTS CORREPONDENCE}

Double entry bookkeeping consists of simultaneous recording and with the same amount of economic or financial operations in two accounts namely in debit of an account and in the credit of the other account. Reciprocal relation between the debit of an account and the credit of the another account established upon economic and financial operations registration on current accounting based on double entry bookkeeping is called accounts correspondence, and accounts between which is establishing such a relation are called correspondent accounts (Gruescu, Nanu \& Tanasie 2009; Bărbulescu, Țâţu \& Ţâţu 2007). The correspondence of the accounts can be set only between asset accounts, when changes occur only in the assets of the balance sheet, either only between liability accounts, when changes occur only on the liability of the balance sheet, or between assets accounts and liabilities accounts, when the economic or financial operation produce concomitant changes by the same amount on both sides of the balance sheet (Enăchescu, 2013; Teodorescu, 2014).

Examples for explanation of the accounts operating rules:

a) It is raised 8.000 lei from the bank to make payments in cash (only cause changes in the asset of balance sheet). It is registered an increase in the asset at the element "Cash", representing the increase of cash on hand of the company, which is registered and concomitant a decrease of asset in the element "Current account at bank" representing the decrease of company cash and it will be reflected in credit of the account of same name, as follows:

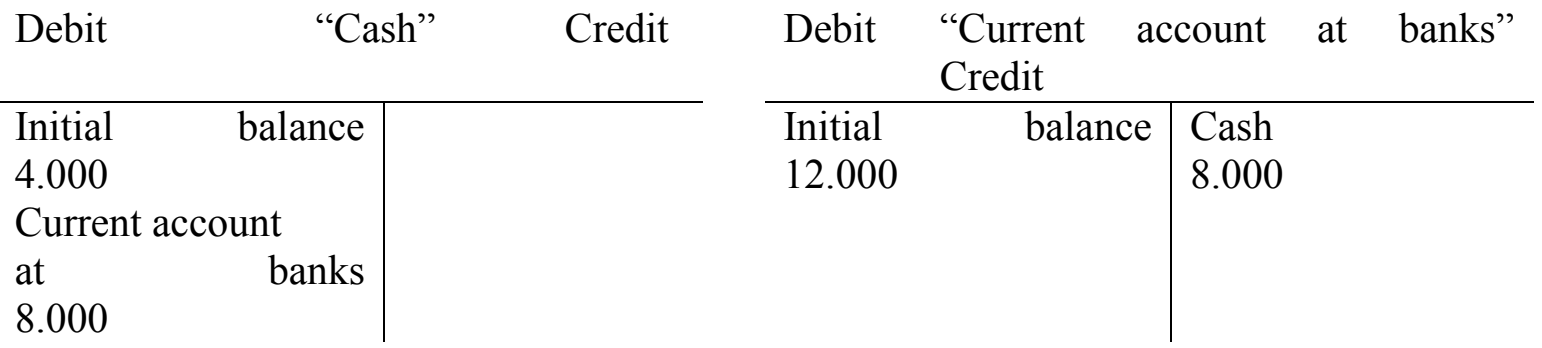

b) The company pays to a supplier an amount of 10.000 lei from a short term credit granted by the bank

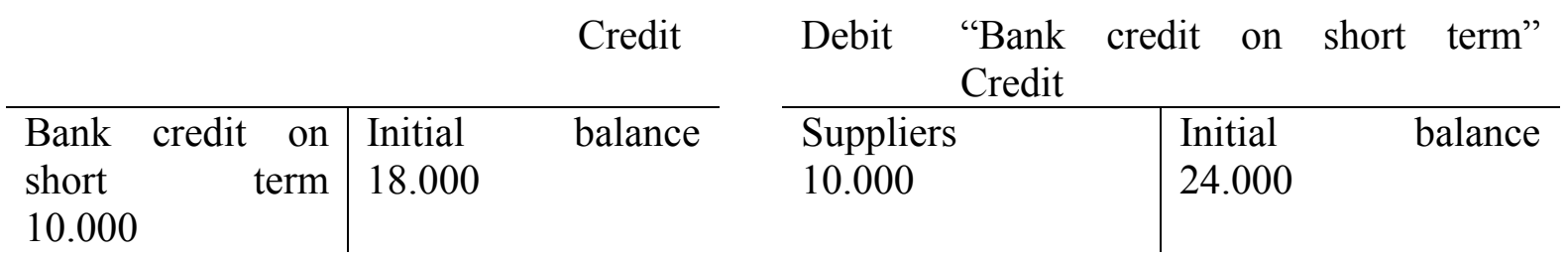

It is noted that there was a decrease of passive element "Suppliers" thereby extinguishing the debt to them (recorded in debit account there) and an increase in the passive element "bank credit on short term" representing growth of the company debt to the bank (Avram, 2010; Lis \& Bajdor, 2013).

c) The company has acquired land whose purchase price is 180.000 lei (this operation will produce changes in both sides of the balance sheet). 


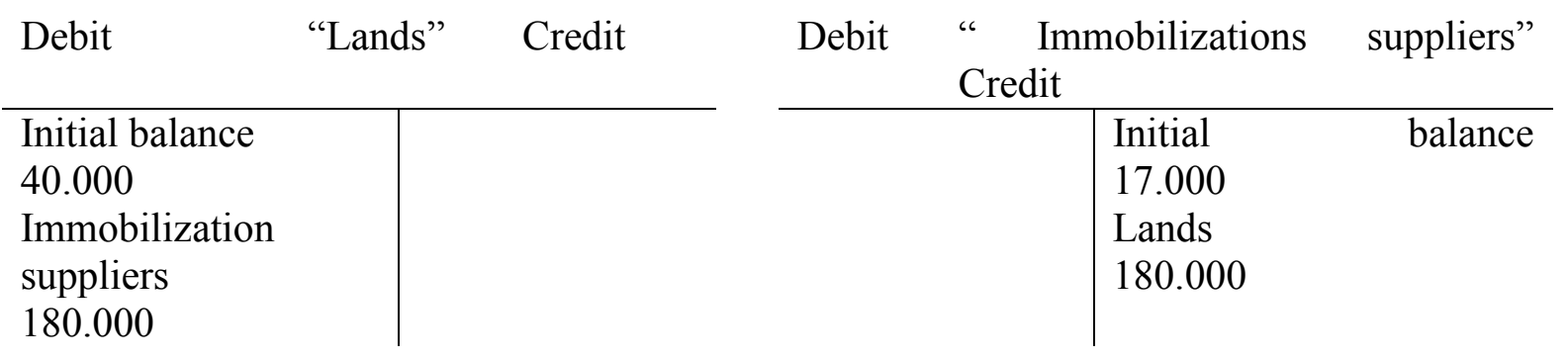

It is noted an increase of active to "Land" element representing the increase of land counter value belonging to company and an increase of passive element "Immobilization Suppliers" representing the increase of trade payables of the company and will be reflected in the credit correspondent account.

d) It is removed from active a full depreciated asset whose value is 40.000 lei.

Debit "Fix Assets" Credit Debit "Depreciation regarding Tangible immobilization" Credit

\begin{tabular}{|c|c|c|c|}
\hline $\begin{array}{l}\text { Initial balance } \\
8.900\end{array}$ & $\begin{array}{l}\text { Tangible } \\
\text { Immobilization } \\
\text { Depreciation } \\
40.000\end{array}$ & $\begin{array}{l}\text { Fix } \\
\text { assets } \\
40.000\end{array}$ & Initial balance \\
\hline
\end{tabular}

By removing an fix asset from active this operation causes a reduction of the active element "Fix Assets" leading to decrease the input value of existing fixed assets in the company, which will be reflected in the credit of that account and hence a decrease of passive element "Depreciation of tangible immobilization" reflecting decreased of depreciation of immobilizations of company that will be registered in the correspondent debit account with the same name.

\section{FORMULA AND BOOKKEEPING RECORD}

Accounting analysis is based on research by accounting or financial operations of each operation by its decomposing into components elements for establishing correspondent accounts and their parts - debit and credit. Accounting analysis performing of economic and financial operations involves the following steps:

Establishing the nature and content of economic or financial operation under analysis;

1. Determination of the modifications that produces economic or financial operation on the balance sheet, namely active and passive elements that are modified, of the meaning of those changes and their economic content;

2. Establishing on the basis of the modified balance elements of correspondent accounts in which will be registered economic or financial operation analyzed;

3. Application of the rules of operation of accounts. 
Accounting Formula is the graphical presentation of each economical or financial operation in correspondent accounts, based on double counting as equal value. Structural it includes: name of the correspondent debit account, name of the corresponding credit account and the amount of corresponding operation that is subject of registration (Tanasie, Tanasie \& Fratostiteanu, 2008; Vlăduţescu, 2013).

In the accounting formula, the account that is debited sits to the left of the sign of equality, due to the fact that the debit appears to the left of an account and the account to be credited is placed on the right side of the equal sign, since credit is the right of account.

The simple accounting formula is that one in which correspondence is established between a single debit account and a single credit account.

The complex accounting formula is that one in which the correspondence is established either between a single debit account and two or more payable accounts, either from one credit account and two or more receivable accounts, or between two or more receivable accounts and two or more payable accounts. For example:

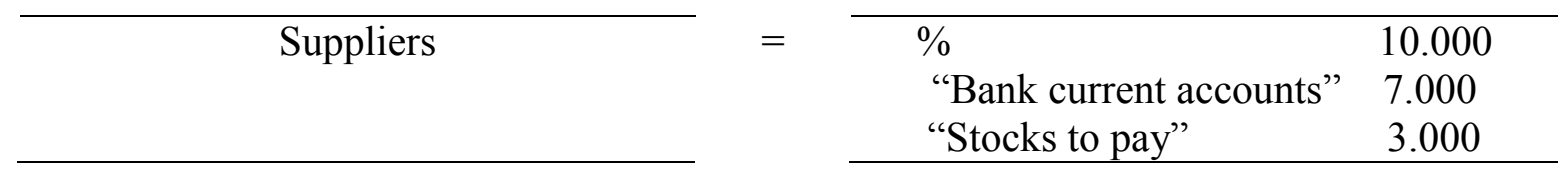

Explanation - payment is made to the supplier in the amount of 10,000 lei follows: 7,000 lei from the funds available from the bank, and for the difference of 3,000 lei is accepted a bill.

By adding to elements of accounting formula of the descriptive explanation of the operation, i.e. the date of its operation and supporting documents that attested it, it is got the concept of accounting entry.

Example of accounting formula:

$\overline{1.000 \text { "Raw materials" }}=\overline{~ " S u p p l i e r s "}$

or

1.000 "Raw materials" $=\overline{\text { "Suppliers" } 1.000}$

Amount for which is applied the accounting formula can be written in front of the account that is debited, or it can be written on both sides of the equal sign, so both account is debited and the account to be credited (Arhip, 2012; Arhip \& Arhip, 2013).

Information flow in accounting: recording the economic and financial operations in the records, the accounting analysis of those operations, the recording of economic and financial analyzed operations in accounts, in chronological order (with day book), and on this basis then, the systemic form (using the document Ledger accounting), preparation of the trail balance and balance sheet. Ledger accounting is presented as open separately cards for each account of current bookkeeping and to record of the economic and financial operations, in it is used the accounting explanation (Stavre, 2012; Grabara, Kolcun \& Kot, 2014). 
The analytical accounting records are those that are made using analytical accounts and are characterized in that in their case, along with the value expression, is used, sometimes quantitative expression (Tomita, Danciulescu \& Bandoi, 2008; Drămnescu, 2013).

The synthetic accounting records are those that are made using synthetic accounts and are characterized in that that they are expressed only in value expression .

An example of the correspondence that is established between several receivable accounts and payable accounts is based on the following economic operation: are received raw materials of 10,000 lei and consumables materials of 5,000 lei for which is settled and payable effects in the amount of 8,000 lei. The following accounting formula is obtained:

\begin{tabular}{l}
\hline 15000 "\% \\
10000 "Rae materials" \\
5000 "Consumable materials" \\
\hline
\end{tabular}

\begin{tabular}{cr}
\hline$\%$ & 15000 \\
"Suppliers" & 7000 \\
"Payable effects" & 8000 \\
\hline
\end{tabular}

After the purpose for which are prepared, accounting formulas are value of two types, namely: current registration and cancellation. After how to register the amounts in the corresponding accounts of the accounting formulas are: in black and in red (Pârvu, 2002; Ionescu, 2014; Powell, 2014).

The accounting formulas of current recording are those that are prepared for recording of financial and economic operations that occur commonly. The registration of amounts in these formulas, is usually, black, reason for which they are also called black recording accounting formulas. This amount shall be added between them, both in debit and credit of the account. The amounts recorded in red have significance of minus sign amounts and are deducted from the amounts recorded based on current accounting formulas in black. They aim to rectify by subtraction of certain amounts and are called accounting formulas of rectification (Siminica, Circiumaru \& Simion, 2012; Borowski, 2013; Vlăduţescu, 2014b).

The accounting formulas of cancellation represent a specific way of correcting accounting mistakes committed before, during registration in the accounts of amounts from economic and financial operations. After how apply the amount of the reversal accounting formulas may be of two kinds, namely reversal black and red. Reversal in black is the cancellation of a previously performed incorrectly accounting formulas by reversing its score sum all in black, then draw the correct accounting formula.

For example, it is considered that the company has got a short term credit at the bank of value 10,000 lei. The accounting formula of registration of this operation was set wrong on both correspondent accounts:

$\overline{\text { "Cash" }}=\overline{\text { "Banks Credits on short term" } 10.000}$

The mistake is detected and it is cancelled in black:

$\overline{\text { "Banks Credits on short term" }}=\overline{\text { "Cash" } 10.000}$

After cancellation of registration done wrong, it is proceeded to the preparation of accurate accounting formula: 
"Current accounts to banks"

"Banks Credits on short term" 10.000

Cancellation in red consists of the cancellation of a previously accounting formulas performed wrong, by its repeating, but with the amount registered in red (or black but boxed) and then drawing the correct accounting formula in black.

\section{CONCLUSION}

The Account is a specific process of the accounting method that ensures the recording of values, chronological and systematic of existence and movement of patrimonial elements. Registration of economic operations in the account in chronological order is based on supporting documents, to ensure the reality of the registrations. At the same time, all the elements are value expressed to allow generalization and centralizing of data and calculating of the result of the exercise. The correct registration of economic operations in accounts and proper use of the provided information by them, requires knowledge of the account structure.

\section{References}

[1] A. Băndoi, I. Tomiţă (2009). Some considerations of the main determining variables in models used to estimate inflation. Finanţe provocările viitorului.

[2] A. Borowski, International Letters of Social and Humanistic Sciences 11 (2014) 1-168.

[3] Maria Nowicka-Scowron, Ioan Constantin Dima, Ştefan Vlăduţescu (2012). The IC Concept in the Strategies of Developing in the Urban and Regional Communication Networks. International.

[4] D. Berceanu (2008). The financing of the firm by bonds. Economic Science.

[5] Ştefan Vlăduţescu, Ella Magdalena Ciupercă (2013). Next Flood Level of Communication: Social Networks. Aachen: Shaker Verlag.

[6] Dan Ionescu, Cristina Pretorian, International Letters of Social and Humanistic Sciences 9 (2014) 49-56.

[7] M. Siminică (2008). Diagnosticul financiar al firmei. Craiova: Editura Universitaria.

[8] O. Arhip, C. Arhip (2012). Beyond 'Customer is King”: Sales and Marketing Promotion. International Conference on Business Excellence 2007.

[9] R. Gruescu, R. Nanu, A. Tanasie (2009). Human Resources Development and ICT Contribution to the Tourist Destination Competitiveness. European Research Studies.

[10] Patricia Martínez García de Leaniz, Ignacio Rodríguez del Bosque, International Letters of Social and Humanistic Sciences 2 (2013) 51-55.

[11] Ştefan Vlăduţescu (2013). The Communication Membranes. European.

[12] Vladimir-Aurelian Enăchescu (2013). Understanding Multicultural Communication and Cooperation Through Multicultural Dobrogea. Journal of Community Positive Practices, 13(2). 
[13] A. Borowski, International Letters of Social and Humanistic Sciences 3 (2013) 69-74.

[14] R. Bărbulescu, D. Țaţu, L. Țâţu (2007). Investment in human capital. EU integration opportunities, Romania within EU: opportunities, requirements and perspective (pp. 430-435). V1. Sibiu: Editura Universităţii Lucian Blaga.

[15] Ioan Constantin Dima, Ştefan Vlăduţescu (2012b). Persuasion elements used in logistical negotiation: Persuasive logistical negotiation. Saarbrucken: LAP Lambert Academic Publishing.

[16] A. Tanasie, R. Tanasie, C. Fratostiteanu (2008). A Fuzzy Clustering Algorithm Application for Monetary Unions. International.

[17] Ştefan Vlăduţescu (2013). A Completion to the Traditions Matrix-Standard - R. T. Craig, Induced by the Transformation of Communication-as-a-Field Membrane in Communication-as-a-Universe Membrane. American International.

[18] Marin Drămnescu (2013). Postmodern Society and Individual Alienation. Revista de PSIHOterapie Experienţială.

[19] M. Siminică, D. Berceanu, D. Circiumaru (2008). The Performances of Industrial Firms from Romania. Correlation Dimension-Indicators of Results. Financial Innovation and Competition.

[20] I. Tomita, D. Danciulescu, A. Bandoi (2008). Pretul de transfer-un aspect fiscal. Analele Universitatii.

[21] M. G. Păun, International Letters of Social and Humanistic Sciences 6 (2014) 42-48.

[22] Ştefan Vlăduţescu (2013). What Kind of Communication Is Philosophy. Jokull.

[23] A. Borowski, International Letters of Social and Humanistic Sciences 4 (2013) 70-74.

[24] J. Tittenbrun, International Letters of Social and Humanistic Sciences 2 (2014) 20-40.

[25] V. A. Enachescu, D. A. Hristache, C. E. Paicu, Review of Applied Socio-Economic Research 4(2) (2012) 93-96.

[26] F. Smarandache, Ş. Vlăduţescu (2013). Communication vs. Information, a Neutrosophic Solution. Neutrosophic Sets and Systems, 1.

[27] Janusz Grabara, Michal Kolcun, Sebastian Kot (2014). The Role of Information Systems in Transport Logistics. International.

[28] F. Smarandache, Ş. Vlăduţescu (2014). Neutrosophic Emergences and Incidences in Communication and Information. Saarbrucken: LAP Lambert Academic Publishing.

[29] Ştefan Vlăduţescu (2014). Eight computational-communicative operations of building information. Mitteilungen Klosterneuburg.

[30] M. Avram, M. Dutescu, L. Puican, Annals of the University of Craiova, Economic Sciences Series 3 (2011)

[31] Andrzej Borowski, International Letters of Social and Humanistic Sciences 2 (2014) 110-121.

[32] Ştefan Vlăduţescu, International Letters of Social and Humanistic Sciences 10(2) (2014) 100-106. 
[33] I. Stavre (2012). Internet and digital technology - influences on audiovisual communication and on teaching at master's degree level, Valencia, 2012, Published by International Association of Technology, Education and Development -ISBN: 978- 84$615-5563-5$

[34] Dan Ionescu, International Letters of Social and Humanistic Sciences 12 (2014) 57-65.

[35] A. Borowski, International Letters of Social and Humanistic Sciences 6 (2013) 86-90.

[36] G. Pârvu (2002). Economia relatiilor europene. Editura Universitaria Craiova.

[37] Tomáš Hes, Anna Poledňáková, International Letters of Social and Humanistic Sciences 2 (2013) 18-31.

[38] Ştefan Vlăduţescu (2014). Four Sources of Uncertainty in Communication Ontology. Journal.

[39] Lis T., \& Bajdor P. (2013). Sales Logistics as a Model Used by Companies Fulfilling Individual Customer's Needs. In: Challenges in Contemporary Management. Monograph. Scientific Editors Anna Lemańska-Majdzik, Piotr Tomski, Sekcja Wydaw. WZ P Czestochowa.

[40] O. Arhip (2012). Characteristics of Meta-Referential Discourse. Philologica Jassyensia.

[41] Jason L. Powell, International Letters of Social and Humanistic Sciences 7 (2014) 22-30.

[42] Ştefan Vlăduţescu (2013). Principle of the Irrepressible Emergence of the Message. Jokull.

[43] M. Siminica, D. Circiumaru, D. Simion (2012). The Correlation between the Return on Assets and the Measures of Financial Balance for Romanian Companies. International.

[44] M. Avram (2010). Management contabil. Editura Universitaria, Craiova.

[45] Bianca Teodorescu, International Letters of Social and Humanistic Sciences 12 (2014) 73-78. 